\title{
Design of a Videolaryngoscope with sensor and pressure alert
}

\author{
Quiroga Josué1 \\ ORCID: https://orcid.org/0000-0001-6819-56743 \\ jequiroga@uce.edu.ec \\ Universidad Politécnica Salesiana, \\ Facultad de ingeniería electrónica \\ Quito-Ecuador \\ Flor Omar ${ }^{2}$ \\ ORCID: https://orcid.org/0000-0002-3455-5982 \\ omar.flor@udla.edu.ec \\ Universidad de las Américas, \\ Facultad de Ingenierías y Ciencias Aplicadas \\ Ingeniería Industrial \\ Quito-Ecuador
}

\author{
Solórzano Santiago ${ }^{3}$ \\ ORCID: https://orcid.org/0000-0002-8154-5277 \\ santiago.solorzano@udla.edu.ec \\ Universidad de las Américas, \\ Facultad de Ingeniería y Ciencias Aplicadas \\ Ingeniería de Software \\ Quito-Ecuador \\ Calahorrano José ${ }^{4}$ \\ ORCID: https://orcid.org/0000-0001-5077933X \\ jose.calahorrano@uce.edu.ec \\ Universidad Central del Ecuador, \\ Escuela de Medicina \\ Quito-Ecuador
}

Recibido (08/02/21), Aceptado (18/02/21)

\begin{abstract}
This work presents the design and construction of a laryngoscope model with camera vision that has a vibrating device to alert the medical specialist when the force exerted causes possible damage to the patient's airway during the intubation process. Design and fabrication considerations are described using Cast Material Position (FFD). The design is validated with the use of a high-fidelity simulator, the performance is compared with commercial models and the criteria of specialists are taken into account to improve all the necessary aspects. The model presented a great functional advantage, providing greater patient safety, reducing the risk of exposure of the internal tissue to high forces in the intubation process, facilitating clinical processes for health personnel.
\end{abstract}

Keywords: Video laryngoscope, intubation, $3 \mathrm{~d}$ printer, PLA.

\section{Diseño de un laringoscopio con sensor y alerta de presión}

Resumen: Este trabajo presenta el diseño y construcción de un modelo de laringoscopio con visión de cámara que posee un dispositivo vibratorio para alertar al especialista médico cuando la fuerza ejercida causa posibles daños en la vía área del paciente en el proceso de intubación. Se describen consideraciones de diseño y fabricación mediante posición de material fundido (FFD). El diseño se valida con el uso de un simulador de alta fidelidad, se comparan las prestaciones con respecto a modelos comerciales y se toman en cuenta los criterios de especialistas para mejorar todos los aspectos necesarios. El modelo presentó una gran ventaja funcional, brindando mayor seguridad al paciente, disminuyendo el riesgo a la exposición del tejido interno a elevadas fuerzas en el proceso de intubación facilitando los procesos clínicos al personal de salud

Palabras Clave: Videolaringoscopio, intubación, impresora 3d, PLA.

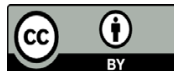




\section{I.INTRODUCTION}

The laryngoscope, also known as a larynx, is a medical device that allows you to see inside the pharynx and larynx. This type of procedure is known as laryngoscopy, and it is performed to examine the glottis and vocal cords in order to perform endo tracheal intubation [1].

EL Laringo, has two main parts: Handle and Leaf. The function of the handle is to allow the user to hold and control the instrument in the most comfortable way possible. Inside there are type $\mathrm{C}$ or AA batteries which, thanks to their voltage and current, allow a light to be turned on to illuminate and improve the visibility of the patient's vocal cords. The blade or also called shovel, serves to separate the epiglottis and the patient's tongue. The blade can be reusable or disposable according to its material. The blade is made up of five parts: Spatula (1), Guide or step (2), flange (3), pick (4) and light bulb (5).

The spatula constitutes the main part of the blade, the bottom part makes contact with the patient's tongue and the top part faces the ceiling. The guide or step projects upward from the sheet towards the ceiling. The flange is projected laterally from the guide, The beak is the tip of the blade that is placed over the vellácula or beyond the epiglottis to raise it directly, the focus allows illumination and is located near the tip of the laryngoscope. There are several sizes of blades on the market, there are three basic types of blades: Macintos curved, Jackson or Wisconsin Straight and Straight with curved tip (Miller). The Macintosh curved blade has a parabolic curve with the straight distal third, which is the distance between the teeth and the vocal cords and allows the tip to be positioned at the angle formed by the epiglottis with the base of the tongue. The Jackson-Winsconsin straight blade and Miller curved-tip straight blade have straight blades that enter below the laryngeal surface of the epiglottis, moving forward and upward thereby elevating the epiglottis. It is useful in cases of flaccid epiglottis and in minor pediatric patients due to the anatomical characteristics.

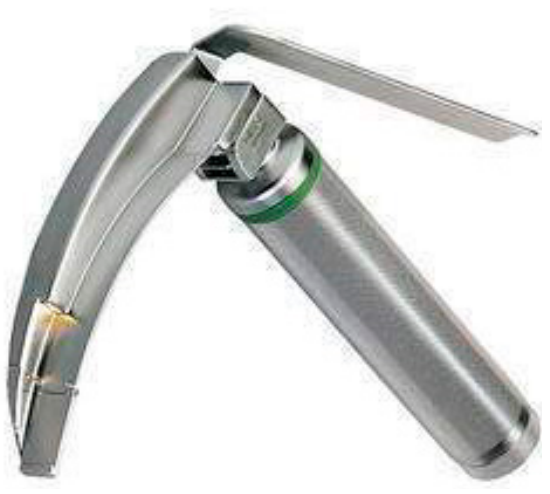

(a)

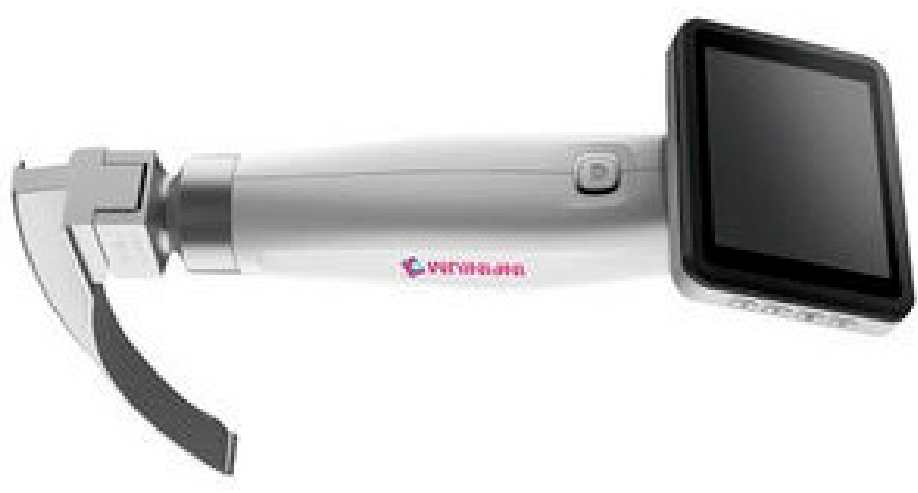

(b)

Fig 1. a. metal laringoscope, b. videolaringoscope

Video laryngoscopes are laryngoscopes that use a video camera to visualize the structures of the airway. Video laryngoscopy enables skill development in airway management techniques by visualizing the glottis without the need to obtain a direct line [3]. When performing intubation with the video laryngoscope and thanks to its camera located in the distal part of the blade, the user is allowed to observe the glottis with panoramic vision without the need to "align its axes". The video laryngoscope has a visual field between $45^{\circ}$ and $60^{\circ}$, as opposed to the distant and tubular vision of $15^{\circ}$ that a classic laryngoscopy provides [4]. Video laryngoscopy, compared to direct laryngoscopy for difficult intubations, provides significantly better vision of the vocal cords, a higher success rate, faster intubations, and less need to optimize maneuvers. Therefore, video laryngoscopy is considered to lead to a clinically relevant improvement in intubation conditions and may be recommended for the management of difficult airways [5].

Through the use of computer-aided drawing software, parts and assemblies can be modeled in 2 and 3 dimensions, allowing the generation of new designs that add new functionalities and improvements in the use of medical implements such as laryngoscopes. This technology provides a tool to create, design, simulate, manufacture, pu- 
blish and manage the data of the design process. [6].

Video laryngoscopes, according to users, compared to traditional Macintosh blade laryngoscopes, have proven to be more user-friendly especially for beginners. They are useful in practical teaching in airway treatments, since said image can be shared through monitors or other devices to be viewed by students [8] [9].

This section describes aspects about the design and that have allowed the implementation of the device, taking into account the structure, materials and electronic systems.

\section{II.DEVELOPING}

This section describes aspects about the design and that have allowed the implementation of the device, taking into account the structure, materials and electronic systems.

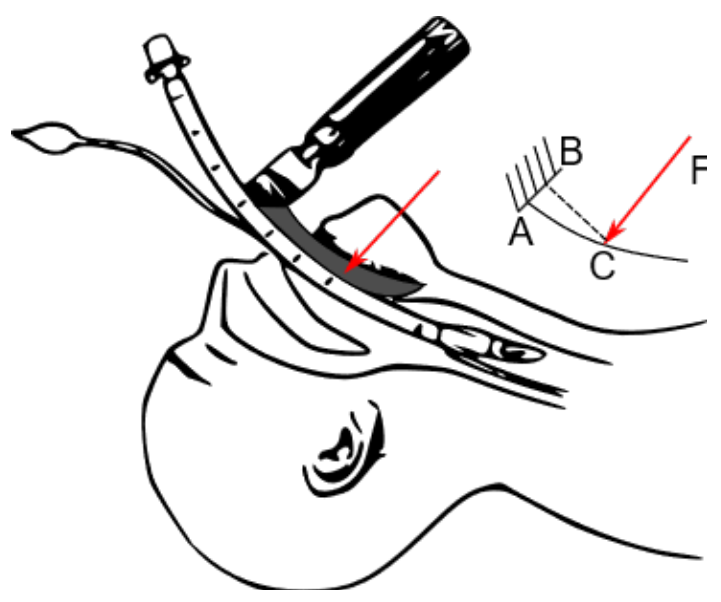

Fig2. Scheme of the intubation process with the use of a laryngoscope

In figure 2 the laryngoscope is observed in the position required for intubation in which the blade enters through the larynx and in the process it will be subjected to a force represented by $\mathrm{F}$ with a perpendicular distance $\mathrm{BC}$, this force represents the reaction of teeth on the blade, this load can be high depending on the patient's conditions.

\section{A. Mechanical Aspects}

Using computer-aided design, components were graphed, based on the geometry of existing designs such as described in [9], Figure 1 presents the reference dimensions.

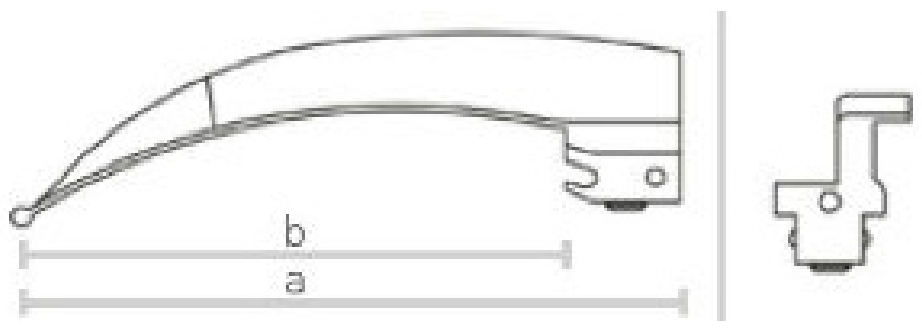

Fig 3. Blade and blade schematic at the end of a laryngoscope.

In figure 2, a diagram of a commercial laryngoscope is presented with a number 3 blade and whose dimensions $\mathrm{a}$ and $\mathrm{b}$ are 135 and $114 \mathrm{~mm}$, these blades vary according to the type of patient and have various dimensions and radii of curvature. In figure 3, a diagram with three representations is presented, figure 3a. presents the structure of the laryngoscope with a mark that highlights the position of the internal mechanism presented in figure $3 \mathrm{~b}$, in which position A describes the location of the piezoelectric sensor that allows interpreting the applied load when the handle is slightly inclined by the action of the strength of the specialist (figure 3c). Around point B, the mobile 
mechanism, attached to the clamping handle, allows light pressure on the sensor at A.

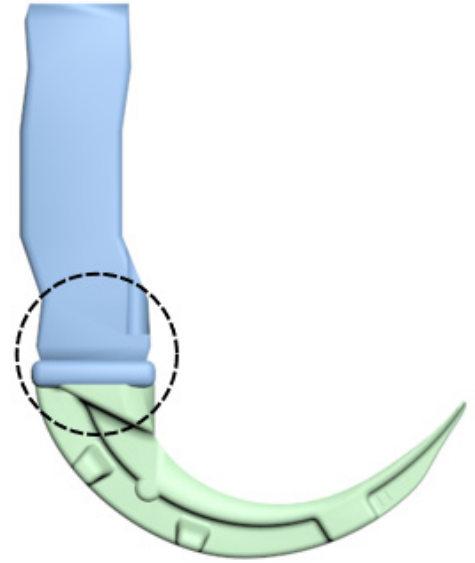

(a)

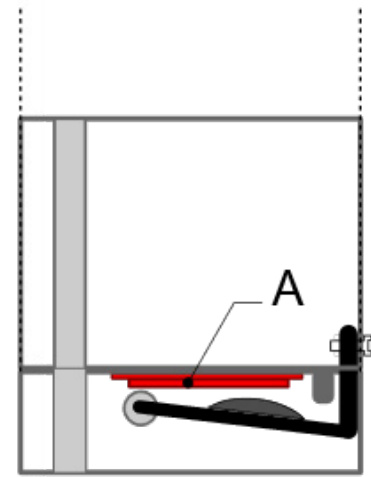

(b)

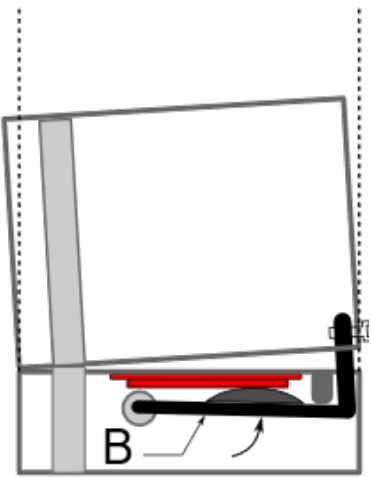

(c)

Fig 4. Designed laryngoscope, a) structure, b) mechanism without force on the handle, c) mechanism pressing piezoelectric sensor.

The geometry proposed allows to provide a hold and support for the blade that must withstand bending moments in the order of $60 \mathrm{~N} / \mathrm{m}$ at its point of union of the two parts. The design contemplates a reduction in stress concentrators and the possibility of incorporating a digital screen that obtains the visualization of the camera that is located near the end of the blade (figure 6).

\section{B. Materials}

Considering the 3D printing process by casting and deposition of molten polymer filament [11], Acryl Nitrile Butadiene Styrene (ABS) is an alternative that provides a resistance of up to $45 \mathrm{Mpa}$ [12], however its use is not considered suitable in contact with human skin, for performance studies using a high fidelity simulator, this material has been chosen for its low cost.

One of the new materials for applications in contact with cell tissue is Rokit's plastics, Skinflex, which is specially designed for interaction with human skin free of carcinogenic elements and which, apart from the elastic property it incorporates, allows elements to be made. such as shoe insoles, bracelets, clothing and accessories and wearables in general. This material complies with the regulations of the North American health agency FDA [13].

\section{Components}

For the implementation of the video laryngoscope, the components and materials that meet the characteristics of operability, low cost and easy accessibility in the national market are selected and described below.

The main structure of the laryngoscope is manufactured with PLA material easily accessible in the local market and which is used in printing processes with fused filament, also with common machines for this process.

A piezoelectric sensor was used (figure 4), which makes it possible to obtain an electrical signal by means of which it will be conditioned and will allow estimating the bending stress applied at the point of attachment of the handle and the blade. 


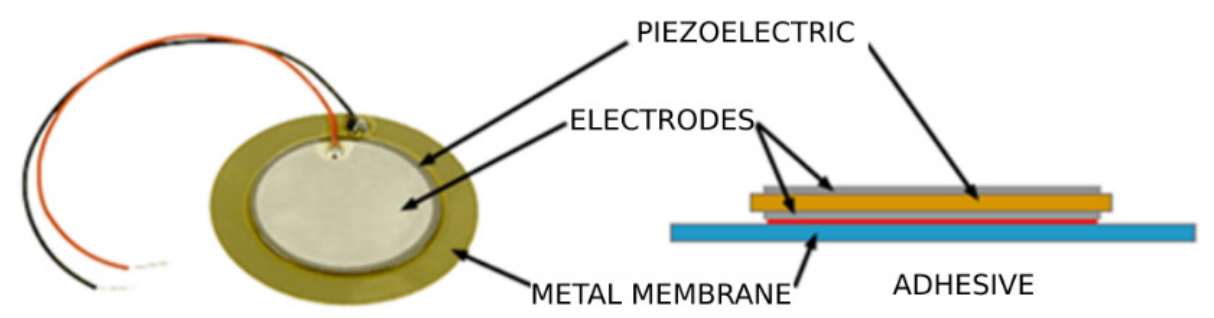

Fig 5. Structure of the piezoelectric sensor.

A wireless endoscope camera was also incorporated, which has IP67 waterproof technology, resists water, camera resolution is $640 * 480(\mathrm{VGA}), 1280 * 720$, viewing angle of 66 degrees, Focal distance of $4 \mathrm{~cm}$, camera diameter of $7.0 \mathrm{~mm}$, it has 6 white LED lights with adjustable intensity, it has an image transmission range of 15 meters via Wi-Fi communication and a maximum of 4 smart devices can be connected simultaneously to observe the image.

\section{III.METHODOLOGY}

For the development of this functional prototype, a characterization of a commercial laryngoscope was first carried out with a Macintosh blade number 3 with dimensions a: $135 \mathrm{~mm}, \mathrm{~b}: 114 \mathrm{~mm}$ and width at the distal end: $14.5 \mathrm{~mm}$ with an arrangement similar to that of the from figure 1.

From the reference dimensions, the other elements of the video laryngoscope were designed with the help of computer-assisted drawing software, whose main structure and final design shown in figure 2. It was also verified that the critical point of the design was not exceed the $45 \mathrm{Mpa}$ limit for phantom tests, considering a maximum force capable of breaking a healthy tooth whose value corresponds to $100 \mathrm{Kg}$, one scheme of distribution of force shown in figure 2.

A mechanism was designed to implement a piezoelectric sensor in such a way that information on the force applied between the gripping handle and the blade of the laryngocope can be obtained, as shown in figures $3 \mathrm{~b}$ and $3 \mathrm{c}$, for this was electrical circuit was implemented.

For the implementation, a 3D printer and polylactic acid polymer (PLA) were used, through which the model made as the figura 6 .

\section{IV.RESULTS}

Figure 6 shows the model obtained in the design process as well as its functionality of transmitting the image to the cellular device. In this case, cable is used, however the design can be improved by wireless communication.

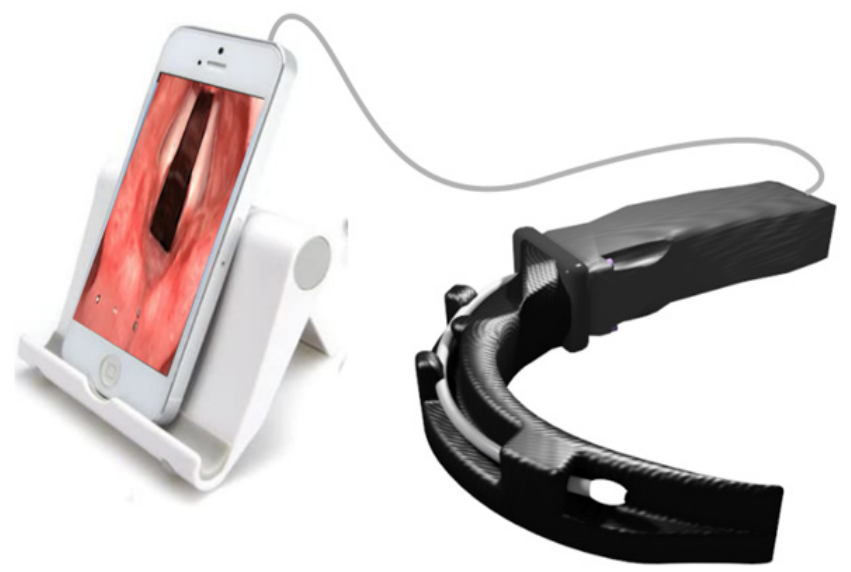

Fig. 6. Video laryngoscope prototype completed. 
The criteria of the specialist doctors who use this device generally propose that this instrument is useful for airway management, facilitating intubation. The visualization it provides is clear and useful for operations carried out on the larynx. According to tests carried out in high-fidelity simulators, it is feasible to provide a grade I laryngoscopy, reducing the optimization maneuvers necessary for successful intubation and allowing the assistant to perform said cooperation under direct vision, as shown in Figure 6.

The design presents adequate rigidity for its use and the built-in sensor manages to transmit a signal when the force exceeds a parameter defined by the programmer. Inside the handle, the embedded system and the connections required to obtain the signal from the piezoelectric sensor were conveniently located.

\section{V.CONCLUSIONS}

Efficacy evaluated by $95 \%$ was demonstrated by 6 doctors who use video laryngoscopes to perform intubations of patients attended by the Anesthesiology Service of the Eugenio Espejo Hospital located in Quito, Ecuador, for these evaluations the high fidelity Siman 3G Simulator was used .

The implementation of a pressure sensor, together with the designed mechanism and its position, adequately provide the possibility of configuring a vibrating mechanism that alerts the user and thus prevents the patient from receiving an overload of forces on the skin of his larynx. The clamping handle has the appropriate size to implement all the electronics for the control of the vibrating mechanism, without enlarging the structure of the device.

The device designed for PLA or ABS material is a suitable alternative for educational processes in medical areas and allows easy handling and use. However, with materials inert to interaction with human skin and devoid of carcinogenic elements, it can be used in patients with a verification of the surface quality after its manufacture.

\section{RECOGNITION}

The contribution of the Central University in the use of the High Faithfulness Simulators for these investigative purposes is greatly appreciated.

\section{REFERENCES}

[1]D, Freitas. "Prototipo De Videolaringoscopio: Wi-Mac-Multivision". Revista Chilena De Anestesia. Volumen (49), número (2), páginas (262-270), 2020.

[2]G, Velázquez. "Videolaringoscopio Artesanal Macintosh". Anestesia en México. Volumen (28). Número (1). Abril 2016.

[3]R, Cooper. J, Pacey. M, Bishop. S, McCluskey. "Early clinical experience with a new videolaryngoscope (GlideScope) in 728 patients”. Can J Anaesth. Volumen (52), número (2), Feb 2005.

[4]C, Billington. P, Kearns. R, Kirkbride. K, Mackintosh. C, Reeve. et al. "A comparison of McGrath and Macintosh laryngoscopes in novice users: a manikin study”. Anaesthesia. Volumen (64), número (11), Nov 2021.

[5]A, Jungbauer. M, Schumann. V, Brunkhorst. A, Börgers, H, Groeben. "Expected difficult tracheal intubation: a prospective comparison of direct laryngoscopy and video laryngoscopy in 200 patients". Br J Anaesth. Volume (102), number (4), April 2009.

[6] A, Caño. M, De la Cruz. "Diseño, ingeniería, fabricación y ejecución asistidos por ordenador en la construcción: evolución y desafíos a futuro", Informes de la Construcción. Volume (59), number 505, pag 53-71, marzo 2007.

[7]V, Mazzanti. L, Malagutti. F, Mollica. "FDM 3D Printing of Polymers Containing Natural Fillers: A Review of their Mechanical Properties". Polymers. 28 jun 2021.

[8]K, Howard. Y, Huang. R, Matevosian. M, Kaplan. R, Steadman. "Video-assisted instruction improves the success rate for tracheal intubation by novices". Br J Anaesthesia. Volume (101), number(4):568-572. Oct 2008.

[9]S, Maya. "Role of video laryngoscopes in anesthesia practice". Revista Mexicana de Anestesiología. Volume (35). Number (1), 344-361, Jun 2012.

[10]M, Kaplan. D, Ward. G, Berci. "A new video laryngoscope-an aid to intubation and teaching”. J Clin Anesth. Volume (14), number (8), 620-626. Dec 2002.

[11]D, Cabrera. G, Massano. S, Fernandez. S, Chaile. et al. "Video-laringoscopio de bajo costo desarrollado con tecnología de impresión 3D”, Revista Chilena de Anestesia, volumen (47), numero 4, 2018.

[12]N, Perez. A, Sanchez. M, Guagliano. M, Villanueva. "HISOPOS, LARINGOSCOPIOS Y AEROSOL BOX-IMPRESIÓN 3D COVID-19”, Ministerio de Ciencia, Tecnología e Innovación-Argentina. 2020 
[13]K, Yoontae. E, Lee. A,Davydov. S, Frukhbeyen. J. Seppala. S, Takagi. L, Chow and S, Alimperti. 3Dprint.com, "Biofabrication of 3D printed hydroxyapatite composite scaffolds for bone regeneration". 30 nov 2020.

\section{RESUEMEN CURRICULAR}

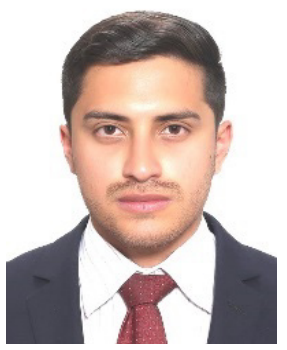

Josué Quiroga, Ingeniero Electrónico de la Universidad Politécnica Salesiana, Desempeña el cargo de Técnico Docente de la Clínica de Simulación Medica y Robótica de la Universidad Central Ecuador. Intereses en Biomédica y Simulación Clínica.

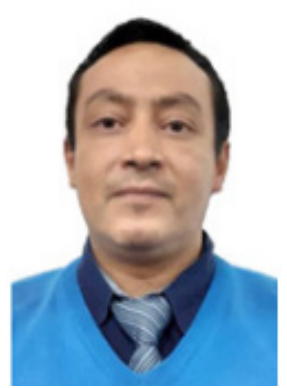

Omar Flor, Ingeniero Mecánico de la Escuela Politécnica del Ejército, Máster en Automática, Robótica y Telemática en la Universidad de Sevilla-España, docente e investigador en la Universidad de las Américas en Quito-Ecuador

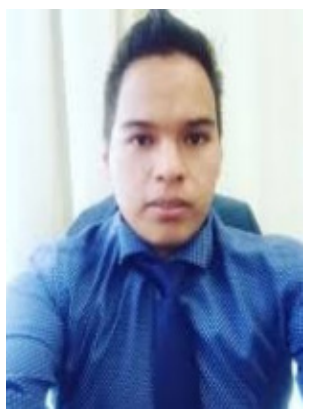

Santiago Solórzano es Máster en Inteligencia Artificial, cuenta con una Ingeniería en Redes y Telecomunicaciones, Tecnología en Electrónica Instrumentación y Aviónica; consultor para el PNUD. Su formación le ha permitido manejar y desarrollar proyectos con tecnología de punta impulsando soluciones de múltiples ingenierías, en el ámbito de la Robótica, IA, IoT, WSN, Electrónica.

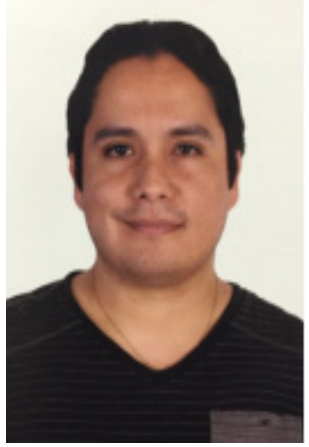

José Calahorrano, Médico de la Universidad Central del Ecuador, Especialista en Cuidados Intensivos en la Universidad San Francisco de Quito, Máster en Gerencia de Salud para Desarrollo Local en la Universidad Técnica Particular, Docente del Postgrado de Medicina Crítica de la Pontificia Universidad Católica del Ecuador, Quito Ecuador Biomédica y Simulación Clínica 